\title{
ОБРАЗ СЕРБІВ У ІСТОРИЧНО-ПРИГОДНИЦЬКІЙ ПОВІСТІ «МИХАЙЛО ЧАРНИШЕНКО» ПАНТЕЛЕЙМОНА КУЛІША
}

\author{
Д. Айдачич
}

\begin{abstract}
Айдачич Д. Образ сербів у історично-пригодницькій повісті «Михайло Чарнишенко» Пантелеймона Куліша. Автор аналізує історично-пригодницьку повість «Михайло Чарнишенко - або Малоросія вісімдесят років тому» Пантелеймона Куліша (1843), написану російською мовою. В повісті, у якій йдеться про події 1762 року, доля пов'язує в останній частині твору головного героя 3 сербами - баном Радивоєм та його донькою Роксандою. Розглядаються етнічні стереотипи сербів як напівазіатів та їх любов до народної пісні у контексті реалій і мотивів повісті П. Куліша.

Ключові слова: етнічні стереотипи; серби; Пантелеймон Куліш; історичний роман; сербські народні пісні; народні звичаї.
\end{abstract}

Айдачич Д. Образ сербов в историческо-приключенческой повести «Михаил Чарнишенко» Пантелеймона Кулиша. Автор анализирует историко-приключенческую повесть «Михаил Чарнишенко - или Малороссия восемьдесят лет назад» Пантелеймона Кулиша (1843), написанную на русском языке. В повести, действие которой происходит в 1762 году, судьба связывает в последней части произведения главного героя с сербами - баном Радивоем и его дочерью Роксандой. Рассматриваются этнические стереотипы сербов как полуазиатов, их любовь к народной песне в контексте реалий и мотивов повести П. Кулиша.

Ключевые слова: этнические стереотипы; сербы; Пантелеймон Кулиш; исторический роман; сербские народние песни; народные обычаи.

Ajdačić D. The Image of Serbs in Historical-Adventure Novel "Mykhailo Charnyshenko" by Panteleymon Kulish. The author analyzes the historical-adventure novel "Mykhailo Charnyshenko, or Little Russia Eighty Years Ago" by Panteleimon Kulish (1843) written in Russian language. In novel that takes place in 1762, the fate connects the main character of the novel with Serbs - ban Radivoy and his daughter Roksanda. The author considers ethnic stereotypes of Serbs as a halfasian, their temperament, their folk songs in the context of realities and motives of the Kulish's novel.

Keywords: ethnic stereotypes; Serbs; Panteleymon Kulish; historical novel; Serbian folk songs; folk customs.

Молодий Пантелеймон Куліш написав першу версію історичної повісті «Михайло Чарнишенко» ще коли навчався в Київському університеті. Про це свідчить лист Михайла Юзефовича до Михайла Максимовича від 2 грудня 1841 року, де серед іншого зазначено, що твір побудований на родинній історії дружини Михайла Юзефовича ${ }^{1}$. Покровитель молодого письменника посприяв виданню його книги російською мовою у Києві в 1843 році.

Підзаголовок історичної повісті «Михайло Чарнишенко - або Малоросія вісімдесят років тому» та перше речення «Років з вісімдесят тому жила Україна ще своїм власним життям» визначають, що пригоди Михайла Чарнишенка відбуваються у шістдесятих роках XVIII століття. Можна ще точніше вказати на рік подій - 1762. Тоді імператор Росії Петро III планував напасти на Данію, щоб повернути Гольштейн Шлезвігу. Це було півстоліття після поразки Мазепи, за рік до усунення Кирила Разумовського як гетьмана у 1763 р., за два роки до обмеження прав козаків і зникнення гетьманської держави з введенням Другої Малоросійської колегії 1764 р. та тринадцять років до остаточного знищення Запорозької Січі (1775р.).

У повісті поєднуються любов до старосвітського побуту, старих звичаїв та ладу життя 3 пригодницькою історією, написаною під впливом романів Вальтера Скотта та Міхала Грабовського. Про вплив Вальтера Скотта зазначили Б. Нейман $(1927)^{2}$, В. Петров ${ }^{3}$, Р. Багрій $(1993)^{4}$, Н. Бєляєва $(2001)^{5}$, Д. Чик (2014) повагу до польського письменника М. Грабовського, з яким він познайомився в його маєтку Олександрівці та потоваришував ${ }^{7}$. Головний герой Михайло - запальний юнак, який, не слухаючи батька, без його благословення залишає домівку, кохану Катерину й посаду

(C) Айдачич, Д., 2016 
канцеляриста та з запалом їде до козацького полку війська російського царя Петра III воювати з голштинцями. Мандрівка веде його до сербського бана Радивоя. В останній частині повісті в героя закохується донька Радивоя - красуня Роксанда.

Сам Куліш у мемуарах про життя згадував час, коли він писав та опублікував повість «Михайло Чарнишенко». Негативну критику Осипа Сенковського, більш відомого як барон Брамбеус, на свою повість він відкидав як думку поляка, а підкреслював, що інший російський критик Степан Шевирьов позитивно сприйняв його роман. Про сербські образи та мотиви у повісті «Михайло Чарнишенко» згадували М. Зеров ${ }^{8}$, Д. Дорошенко $(1922)^{9}$, В. Башманівський, Л. Башманівська $\left(2009^{10}\right.$, Л. Задорожна $(2010)^{11}$, Т. Матвеєва $(2010)^{12}$, Л. Нечаюк $(2011)^{13}$ та ін.

Більше уваги сербським мотивам присвятила Олена Дзюба в оглядовому тексті «Образи сербів в українській літературі», що охоплює твори українських письменників від Пантелеймона Куліша до романів Олександра Устенка (2000) та Вадима Пеунова (1999) ${ }^{14}$. Львівський дослідник Євген Нахлік аналізованому тут твору присвятив декілька сторінок у книзі «Українська романтична проза 20-60-х років XIX ст.» $(1988)^{15}$ та грунтовному дослідженні «Пантелеймон Куліш: Особистість, письменник, мислитель» ${ }^{16}$. Він звертає увагу на вказані автором джерела знань про сербів, про риси героїв та їхнє ставлення до козакі ${ }^{17}$. Львів'янин Василь Івашків, поєднуючи знання фольклориста та літературознавця, показав захоплення Куліша-романтика Гомером, народними піснями ${ }^{18}$.

У цьому тексті ми хотіли б розглянути деякі аспекти повісті молодого Куліша більш детально, ніж у попередніх літературознавчих працях.

\section{Про сербську мову в повісті Пантелеймона Куліша}

Олена Дзюба у згаданій статті пише: «Суттєвою при створенні образу Радивоя $є$ i його мовна характеристика. Бан щедро пересипає свою мову народно-пісенним зворотами, образами, сербськими словами» ${ }^{19}$. Свген Нахлік стисло і влучно змальовує способи використання сербських слів: «Серед українських письменників Кулішеві належить перша спроба впровадження до літературного тексту сербських слів та висловів сербської народної пісенности у вигляді аплікацій, парафраз, алюзій, зокрема згадок про оспіваного в народі «славного витязя» Марка Кралевича» ${ }^{20}$.

У повісті Куліша «Михайло Чарнишенко» Радивой та інші серби вживають рідномовні слова, які письменник наводить та дає пояснення їхного значення. Можна припускати, що Куліш користувався сербсько-латинсько-німецьким словником Вука Караджича («Српски рјечник», 1818). Коли у тексті використовується слово «Храбар», письменник звертає увагу на фонетичну особливість, що серби не вимовляють звук ' $x$ '. Літеру 'х' Вук Караджич увів у цетинському виданні прислів”їв «Српске народне пословице и друге различне као оне у обичај узете ријечи» (1836). В алфавіті з «Буквара» 1827 р. у переліку літер зна-

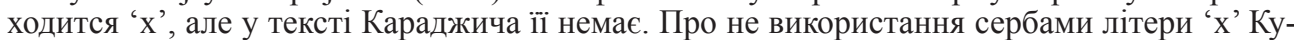
ліш міг дізнатися від учителів-славістів або з книг. Сербські слова, які він використовує без перекладу, часто стосуються боїв та збройних зіткнень: кула (укр. башта), баряктар, гайдукувати, кавга, мейдан, джевердана, освєта, пов'язані з лексикою народних пісень, але наводить автор також слова гуя, друм, крило, книга (у значенні лист) побро (від побратим). Коли письменник використовує слово нахія у реченні «бан повернеться до своєї нахії $\rangle^{21}$, він дописує широку примітку до тексту зі щорічника «Даница» Вука Караджича для 1827 року, якою пояснює, що це назва успадкована від тюрків для назви територій, 3 котрих складається пашалик. Мотив гайдукування виступає декілька разів, а автор опирається на текст Юрія Венелина ${ }^{22}$ про пісні задунайських слов'ян. У мові бана та його підлеглих сербів П. Куліш використовує також образні назви для людей гуя, десно крило. Деінде у тексті вказується на значення виразів, наприклад, до слова освєта (помста за убивство), додається вираз «кажуть у них освятити душу убитого».

Цікавим $є$ слово бан, що багато разів повторюється. У примітці автор пише: «Ватажки їхні, що ділили Сербію поміж себе на багато клаптів і які звали себе кралями банами, князями та войводами». Воно більш притаманне західним говіркам та хорватській історії. Куліш дає пояснення: бан у сербів значить князь. Розлючений бан, крім образливого гуя, вживає зневажливі слова українських говірок як гунсвот (гунцвот). Запорожець Мартин 
Щербина, якому бан подарував життя, стає близьким до бана. Він намагаєтся іноді використовувати і сербські слова, наслідуючи бана. До цього бан жартівливо ставиться, виражаючи це словами, що шаблею він краще володіє ніж мовою.

\section{Народні думи у світобаченні бана та письменника}

Вук Караджич у сорокових роках XIX ст. у слов'янському світі був визнаним ученим, письменником і членом кількох наукових товариств та академій, отож не дивує, що Куліш у історичній повісті показав добру обізнаність із сербською народною епічною піснею.

Сербські народні пісні завдяки книгам Вука Караджича були загально відомими освіченим слов'янам. Коли Михайло Максимович робив свою добірку українських народних пісень, він мав взірець збірки Вука Караджича. Розподіл пісень на чоловічі та жіночі підтверджує, що Максимович був хорошим знавцем праці Караджича та його збірок сербських народних пісень. Той факт, що кандидатура Караджича розглядялася як можлива на посаду викладача Київського університету св. Володимира ${ }^{23}$, підтверджує повагу до нього в українському освіченому суспільстві. На той час вже були відомі переклади Терези Албертини Луїзи фон Якуб німецькою ${ }^{24}$, Востокова та Пушкіна російською ${ }^{25}$, Джона Боуринга англійською ${ }^{26}$, а в альманасі «Русалка Дністрова» (1837) і перші українські переклади з сербської мови - ліричних народних пісень із «Песнарици» Караджича (1814). Ізмаїл Срезневський після знайомства з Вуком Караджичем у Відні в 1841 р., опублікував у Москві у 1846 р. першу його біографію27, а за його сприяння Караджич став почесним доктором університету у Харкові.

Олена Дзюба пише про щедре використання фольклорних мотивів у повісті «Михайло Чарнишенко» ${ }^{28}$. Літературознавець Євген Нахлік згадує збірки Караджича першого видання у Лейпцігу, але з огляду на обмеження обсягу не присвячує уваги деталям посилань та питанню, які саме пісні згадано ${ }^{29}$, що надає нам можливість проаналізувати, які ж персонажі й мотиви використано. Свген Нахлік згадує також джерела Куліша за його авторськими примітками. Стосовно сербів це сербські народі пісні Вука Караджича (видання в Лейпцігу), його альманах «Даница» (1827) та праця Юрія Венелина «О характере народных песен у словян задунайских» (1835).

Пантелеймон Куліш під час написання повісті міг користуватися перекладами, але вміле оперування сербськими думами дозволяє припускати, що письменник міг їх читати в оригіналі сербською мовою. Коли в повісті П. Куліш пише «річка тече кривава й укрита трупом», це алюзія пісні найстаршої епохи «Марко Краљевић познаје очину сабљу», в якій дівчина-туркиня витягає важко пораненого бійця з кривавої річки Мариці (серб. «Од сунца се вода замутила, Ударила мутна и крвава»). Автор наводить описи із сербських пісень: «видно крізь їхні рани чорну-печінку», що справді $\epsilon$ поширеною епічною формулою «виде му се џигерице беле/црне» (з пісень III-ої книги Вука Караджича «Гавран харамбаша» та «Женидба Сењанина Иве», а також «Анђелко Вуковић и Синан кесеџија» (з IV книги). У тексті зустрічаються також усталені епітети, формульні словосполучення «моє десно крило», «руйно вино», пушку джевердану, гуйо люта, ситна книга, тридесет на єднога, керваві врани, между очі чарне, як співається в Сербських піснях. Коли бан звертається до запорожця ( $О$ Щербино, моє десно крило! - оповідав Радивой маніром сербських пісень, на який була настроєна його уява»), письменник представляє читачу як особливість серба його мислення народними віршами. У повісті так зображено, що серби говорять і в побутових ситуаціях високим стилем народних пісень. Іноді письменник дає пояснення «Изити на мейдан юначки, мейдан диелити, у Сербів значить - вийти на гериьь», або дає повний десятистопні сербський вірш у транслітерації «Авай, побро! весела ті майка!».

Декілька прикметників повторюється у сталих зворотах грізний бан, лютий бан, похмурий бан, невгамовний бан, що дозволяє читачеві подумати, що вони є сталими епітетами народних пісень сербів. Таких словосполучень немає у збірках Караджича. Це підказує, що Куліш, розуміючи формульну поетику, вдало вигадував словосполучення під задуманий образ свого героя, бана Радивоя.

Примітки П. Куліша іноді спрямовані на те, щоб розвіяти сумнів у сказаному. Щоб читач не думав, що представлене - перебільшення, автор запевняє, що він саме так, су- 
воро, описує дійсність. Героїчність образа Радивоя письменник підтверджує також його славним родоводом. Своїм славним предком Радивой називає у народній пісні оспіваного Вучка Любчича, який отримав кулу як нагороду за хоробрість, виявлену у перемозі над 60-ма ворогами ${ }^{30}$.

Коли оповідач хоче представити усю красу та могутність бана Радивоя, він уявляє собі творця думи, що оспівує його. При цьому він вживає слово «бард», яке пов'язувалося після шотландського Осіяна Джеймса Макферсона зі співаками-майстрами. «Радівой у своєму півазіятському убранні: в шапці з білим пером, у блискучому панцері, з булавою Марка Кралевича у руці, міг би надихнути того співця, якому дзвін зброї так само до душі, як i дзвін струн, і сербський бард у натхненній імпровізації своїй неодмінно сказав би, що кінь його стрибнув “на три списи уперед і на чотири уверх до неба", як кінь Мілоша Войновича, що проводжав у весільному поїзді славетного краля Степана Сильного» ${ }^{31}$.

Письменник тут нагадує про славетну думу «Весілля цара Душана» («Женидба цара Душана»), в якій родич царя під виглядом пастуха допомагає уникнути усіх перешкод, які постають перед сватами. Кулішу сподобалася картина уявного «співця», тож трохи пізніше він продовжує: «Сербський бард вишукав би в природі фарби, що чудово пасували б і до образа грізного Радивоя, й пишного Щербини, й стрункого Михайла».

Улюблені пісні Радивоя - пісні про героя Марка Кралевича, які він і сам співає на коні, як пісню про смерть Кралевича Марка «почав оп'ять він наспівувати про те, як Марко Кралевич, умираючи, потрощив на шматки свою шаблю щоб вона не дісталася туркам» ${ }^{32}$ або «мугикуючи крізь зуби улюблену свою пісню про те, як Марко Кралевич знайшов батьківську шаблю» ${ }^{33}$. Шабля 3 двох народних пісень про Марка Кралевича (у перекладах Михайла Старицького, Марка Короленка чи Марка Королевича) має значення і для сюжету самої повісті (пісні «Смрт Краљевића Марка», «Марко Краљевић познаје очину сабљу»). Коли Радивой знаходить шаблю незнайомця, Щербина, як посередник між баном Радивоєм та його донькою, рятуючи голову Михайла, сербу нагадує його улюблену пісню та порівнює вчинок Роксанди з вчинком дівчини-туркені: «по-християнському милосердію, точнісінько так, як та туркєня дівойка, що перейняла порубаного юнака на річиі Мариці... Пам'ятаєш, як у вас співають у пісні?... А юнак, той вже ніхто ж був, як батько вашого Марка Кралевича» ${ }^{34}$.

Цікавими є роздуми Щербини, який порівнює сербський народний інструмент гусла 3 бандурою. «От сміха! Хотять на одній струні славити своїх предків! Хіба ж так прославляють у нас храбрих лицарів? Як зарокочеш на всіх тридцятьох струнах бандури, то здається, немов душі загинувших у бою козаків зібралися навколо тебе роєм та заговорили під стук ковшів та дзвін шабель» ${ }^{35}$.

Можливо, уявлення про вигляд гусел та гусляра Куліш отримав з гравюри, надрукованої у другій книзі сербських народних пісень. Караджич у листі до Єрнея Копитара від 27 серпня 1823 р. описує малюнок (Zeichnung): «Еро сједи, пак дигао главу, какогођ Слијепац Вилип, а остали се око њега начетили па слушају». («Еро сидить, підняв голову, нібито старий гусляр Пилип [Вишніч], а інші зібралися коло нього та слухають»). Сербський фольклорист Воїслав Йованович припускає, що в образі гусляра зображений сам Вук Караджич ${ }^{36}$.

Сербські народні пісні відтворюють «локальний колір» екзотичного світу, підкреслюють його суворість та криваву історію сербів, також їхню пам’ять в усній традиції.

\section{Де знаходиться бан Радивой}

За Оленою Дзюбою, пригоди приводять молодого Михайла до Нової Сербії. За історією, Нова Сербія з генералом Хорватом, а також Слов'яносербія Шевича і Прерадовича на Сіверському Донці у ці дні проживала останні дні. У самій повісті ці території не названі. Шляхи не ведуть Михайла до Нової Сербії, і тому немає підстав пов'язувати володіння бана з Новою Сербією. Нахлік теж згадує сербських переселенців та територію під владою сербських офіцерів, але він їх пов'язує з Слов'яносербією у луганському краю ${ }^{37}$. Розбіжність у тексті Дзюби та Нахліка спонукає ретельно пошукати у повісті згадані топоніми, щоб визначити, якими шляхами рухався молодий Михайло, а також, чи письменник згадує ім'я когось 3 переселенців-офіцерів, пов'язаних з територіями, наданими сербам за наказом імператриці Катерини II. 
Михайло від'їжджає з Глухова, згадується недалекий сумський Вороніж, рідне містечко Куліша. Він їде в Гадяч, письменник згадує і ряд містечок, якими він мав би проїхати - тому що батько нареченої Михайла, полковий суддя Животовський їде за ним - шлях лежав через Ярославець, Мутин, Конотоп, Стародубівку, Хмелів, Ромен та Липову Долину на відстані сто вісімдесят семи верст. Вирішив їхати цим шляхом, упевнений, що Михайло іншої дороги не міг обрати. На шляху Михайла згадуються річки Клевень та Сейм, «на самому кінці рубежа поміж Глуховським та Кролевецьким повітами» (XIV).

Коли через степ «бідний козак, з-під Ніжина». Середа, запорожець Щербина та Михайло заходять в гості до пана Бардака, запорожець добродію відповідає: «Добре “убрали вже нас у мішок” москалі своїми лініями, фортецями та Сербськими ротами; “треба їм ще вигадати: тільки, як зав'язати цей мішок”. Та що робитимеш, як що така воля божа! Не дарма ж у нас здавна ведеться пророцтво, що буде колись на Москві “Біла Цариця", що розжене запорожців, немов диких чайок, по всьому світу!» ${ }^{38}$.

Згадування «сербських рот» стосується недовговічних автономних утворень Нової Сербії та Слов'яносербії, як і нащадків сербських офіцерів, що приїжджали і в першій половині XVIII ст. Серби у повісті до того, як їх названо сербами, описуються за виглядом одягу: «червоні жупани .... христяться по христіянському». В червоних жупанах, за історичними даними, були одягнуті вояки Ізюмського полку ${ }^{39}$.

Літературознавець Василь Івашків писав: «На думку С. Шевирьова, очевидне новаторство Куліша полягало передусім в ідеї “відтінити характер одного племені іншим” [...], хоча письменник наче і не згадує про ворожнечу між козаками і новосербами, яка "була породжена поселенням новосербів у степу від річки Синюхи до верхів'я ріки Інгулу, яку запорожці $з$ давнини вважали своєю безумовною власністю”» ${ }^{40}$.

\section{Образ серба Радивоя і його доньки}

Образ сербського бана, пов'язаний з Угорщиною та кривавою, але і любою Сербією, можна розглядати з точки зору імагології, теорії етнічних стереотипів. Враховуючи багатокомпонентний етнічний склад Російської імперії та історичні обставини, цей історичний роман можна трактувати і з позицій постколоніальної теорії. Цей аспект $є$ тим важливіший, що повість написано перед створенням Кирило-Мефодіївського братства та вигнанням Куліша, як одного із засновників братчиків, в Тулу. 3 одного боку, серби - чужинці, які забрали деякі права корінного населення, але, з іншого, вони теж страждають. Автор підреслює їхню відмінну природу, яка відображається як у вигляді, так і в поведінці сербів. Олена Дзюба цитатами ілюструє неординарну зовнішність бана Радивоя та його доньки Роксанди, підкреслює їхню любов до батьківщини: «Куліш змальовує Радивоя як національного героя, ім'я якого живе в народі, безстрашного юнака, з яким серби пов'язують усі свої надії на визволення від турків, якого ждуть у себе на батьківщині, “як орлята на свою мати”. Сам Радивой сповнений мрій про повернення у рідні краї та помсту ворогам» ${ }^{41}$.

В описах бана Радивоя та його доньки пов'язує їх із тюрками та азіатами: «Скоріш усього можна було уважати його за турчина, як би не перечив тому великий золотий хрест, що висів у нього на грудях < ..> Роксанда - азіатське вбрання, багате й ніжне».

Дикість, суворість, несамовитість, як психічні риси героїв, повторюються. Цей факт цікавий тим, що серби приходили у географічному сенсі з південного заходу. Їхнє представлення як тюрків, що носять хрест, очевидно, надає їм рис східного народу. Сербів представлено як пристрасних орієнтальних людей. «При вході в монастир, перебудований у фортецю, видно жовтий прапор 3 мечем та мертвою головою <... На фронтоні грубо зліплена була та сама емблема, що й на прапорі - меч і мертва голова <...> Радивой несамовитий, лютий, грізний, похмурий, але багатий з золотом та серебром. Вина їм ніколи не бракувало. Він вивіз з Сербії багато золота й, розкидаючи щедро гроші, здавалося, не знав їм ціни. Це й найбільше притягало до нього серце безрідних молодців, мимо всієї його жорстокості ${ }^{42}$.

Характер похмурого та суворого Радивоя письменик пояснює його боротьбою з турками. Він мріє повернутися в свою Сербію. Його пристрасна донька, красуня Роксанда, виглядає ніжно, але коли Михайло захоче повернутися до Катерини, іiї дика натура від- 
кривається повністю, а письменник ï представляє як амазонку, котра безмилосердно убиває суперницю.

Зображення Радивоя та його пристрасної доньки в історично-пригодницькій повісті «Михайло Чарнишенко» Пантелеймона Куліша $є$ першим у українській літературі розгорнутим описом сербів. Зрозуміло, що серби XVIII століття і після повісті Куліша приваблювали увагу авторів, що писали історичну прозу російською чи українською мовами, тому що сербські офіцери та солдати, переселенці з Австрійської імперії, були учасниками тодішніх історичних подій. Зображення сербів як азіатів у повісті Куліша цікаве тим, що автор поєднує повагу із зневагою до таких рис. Пояснення таких суперечностей заслуговує на подальші літературознавчі дослідження.

${ }^{1}$ Нахлік $\epsilon$. Пантелеймон Куліш: Особистість, письменник, мислитель: - Київ: Український письменник, 2007. - Т. 2. - С. 99-100.

${ }^{2}$ Нейман Б. Куліш і Вальтер Скотт // Пантелеймон Куліш. Збірник праць Комісії для видавання пам'яток новітнього письменства (Збірник історично-філологічного відділу УАН, № 53). - Київ: [Б. в.], 1927. - С. 126-156.

${ }^{3}$ Петров В. Вальтер-Скоттівська повість з української минувшини // Петров В. Розвідки. Київ: Темпора, 2013. - Т. 1. - С. 272-293.

${ }^{4}$ Багрій Р. Шлях сера Вальтера Скотта на Україну («Тарас Бульба» М. Гоголя і «Чорна рада» П. Куліша в світлі історичної романістики Вальтера Скотта). - Київ, 1993. - 296 с.

${ }^{5}$ Беляєва $H$. Поетика англійського готичного роману та історична проза Пантелеймона Куліша // Вікно в світ. - 2001. - № 3. - С. 45-153.

${ }^{6}$ Чик Д. «Михайло Чарнышенко, или Малороссия восемьдесят лет назад» П. Куліша та романи В. Скотта: проблеми рецептивної та компаративної поетики // Вісник Запорізького національного університету. - 2014. - № 2. - С. 265-275.

${ }^{7}$ Пантелеймон Куліш: Матеріали і дослідження. - Київ-Нью-Йорк, 2000. - 413 с.

${ }^{8}$ Зеров М. Твори: У 2 т. - Т. 2: Історико-літературні та літературознавчіпраці / Упоряд. Г. П. Кочур, Д. В. Павличко. - Київ: Дніпро, 1990. - 601 с.

9 Дорошенко Д. Пантелеймон Куліш. - Київ-Ляйпціг, 1922. - 207 с.

10 Бамманівський B. I. Творчість Пантелеймона Кулішав літературно-критичних студіях М. К. Зерова / В. І. Башманівський, Л. А. Башманівська // Вітражі: Збірник матеріалі в викладацькостудентських наукових читань. - Житомир, 2009. - С. 85-88.

11 Задорожна Л. М. Художня концепція історії в романі П. Куліша «Михайло Чарнишенко» // Літературознавчі студії. - 2010. - Вип. 29. - С. 153-159.

${ }_{12}$ Матвесва T. Семантика язичницьких і християнських елементів в історичних романах П. Куліша // Вісник Харківського національного університету. - 2010. - № 910. - Серія: Філологія. Вип. 60. - Ч. II. - С. 147-156.

${ }^{13}$ Нечаюк Л. Релевантність художнього зображення в П. Куліша й у В. Малика // Літературознавчі студії. - 2011. - Вип. 33. - С. 374-379.

${ }_{14}$ Дзюба O. Образи сербів в українській літературі // Сеоба Срба у Руско царство половином 18. века. - Нови Сад, 2005. - С. 483-484.

${ }^{15}$ Нахлік $C$. Українська романтична проза 20-60-х років XIX ст. - Київ: Наукова думка, 1988. $318 \mathrm{c}$.

${ }^{16}$ Нахлік $C$. Пантелеймон Куліш: Особистість, письменник, мислитель. - Київ: Український письменник, 2007. - Т. 1: Життя Пантелеймона Куліша наукова біографія. - 463 с.; Його ж. Пантелеймон Куліш: Особистість, письменник, мислитель. - Київ: Український письменник, 2007. - Т. 2: Світогляд і творчість Пантелеймона Куліша: наукова біографія. - 464 с.

${ }^{17}$ Нахлік С. Пантелеймон Куліш: Особистість, письменник, мислитель. - Т. 2. - Київ: Український письменник, 2007. - С. 99-104.

${ }^{18}$ Івашків B. Художня, літературознавча і фольклористична парадигма ранньої творчості Пантелеймона Куліша. - Львів, 2009. - 448 с.; Його ж. Європейські фольклорні та літературні мотиви у творчості Пантелеймона Куліша 1840-х років // Вісник Львівського університету. - Серія: Філологія. - 2007. - Вип. 41. - С. 3-15.

${ }_{19}$ Дзюба О. Образи сербів в українській літературі // Сеоба Срба у Руско царство половином 18. века. - Нови Сад, 2005. - С. 483.

${ }^{20}$ Нахлік . Пантелеймон Куліш: Особистість, письменник, мислитель. - Т. 2. - С. 101.

${ }^{21}$ Куліш П. О. Чорна рада. Михайло Чарнишенко : [iст. романи] / Пантелеймон Куліш; [упоряд. та передм. А. Яцько]. - Київ: Персонал, 2008. - (Бібліотека української героїки; вип. 1). - С. 370.

${ }^{22}$ Там само. - C. 372.

${ }_{23}$ Чмир О. Сербістика в Університеті св. Володимира // Українсько-сербський збірник. Украс. 2009. - Вип. 4. - С. 159. 
${ }^{24}$ Volkslieder der Serben / Metrisch übersetzt und historisch eingeleitet von Talvj (Therese Albertine Luise von Jakob). - Halle, 1826. - $330 \mathrm{~s}$.

${ }^{25}$ Шекара Л. Српска народна пјесма у руској књижевности 19. вијека. - Бања Лука; српско Сарајево, 2000. - $357 \mathrm{c}$.

${ }^{26}$ Servian Popular Poetry / Translated by John Bowring. - London, 1827. - 235 p.

27 Ізмаїл Іванович Срезневський (до 200-річчя від дня народження): біобібліогр. Покажчик / Укл. О. С. Журавльова, Н. Г. Мацнєва, Е. Д. Дроснева, В. Петрович, Б. Ріфл, Д. Шкергет; вступ. ст. С. Ю. Страшнюка, С. Х. Широкорад; наук. ред. С. Ю. Страшнюк; бібліогр.ред. С. Б. Глибицька, Ю. Ю. Полякова. - Харків: Харківський національний університет імені В. Н. Каразіна, 2012. - 182 с.

28 Дзюба О. Образи сербів в українській літературі. - С. 483.

${ }^{29}$ Нахлік С. Пантелеймон Куліш: Особистість, письменник, мислитель. - Т. 2. - С. 102.

${ }^{30}$ Вучко Љ. (Вук Карацић. Српске народне пјесме. - Књ. III, 61).

${ }^{31}$ Куліш П. Чорна рада. Михайло Чарнишенко : [іст. романи]. - С. 410.

32 Там само. - C. 379.

33 Там само. - C. 377.

34 Там само. - C. 407.

35 Там само. - C. 385.

${ }^{36}$ Јовановић Војислав М. О лику Филипа Вишњића и других гуслара Вукова времена // Зборник Матице српске за књижевност и језик. - Нови Сад. - 1954. - Св. 2. - С. 67-96. - URL: rastko.rs/ likovne/vm_jovanovic-visnjic_c.html (дата звернення: 10.01.2016).

${ }^{37}$ Нахлік С. Пантелеймон Куліш: Особистість, письменник, мислитель. - Т. 2. - С. 102.

${ }^{38}$ Куліш П. Чорна рада. Михайло Чарнишенко: [іст. романи]. - С. 314.

39 Дякую за інформацію Олександру Жолтобродову.

40 Івашків B. Європейські фольклорні та літературні мотиви у творчості Пантелеймона Куліша 1840-х років. - С. 19.

41 Дзюба О. Образи сербів в українській літературі. - С. 483.

${ }^{42}$ Куліш П. Чорна рада. Михайло Чарнишенко: [іст. романи]. - С. 353. 